LOCAL WISDOM, 12 (1): 71 - 78, 2020
Local Wisdom Scientific Online Journal
ISSN: 2086-3764

\title{
Local Wisdom-Based Stories in Conserving Water Resources
}

\author{
Dian Novita Dewi ${ }^{1^{*}}$, Irene Nany Kusumawardani ${ }^{2}$, Alies Poetri Lintangsari ${ }^{3}$
}

123English Language Education Program, University of Brawijaya, Indonesia

Corresponding Author: : diannovita@ub.ac.id

\begin{abstract}
Keywords: local wisdom, stories, water resources, sustainability

Along with the rapid development of technology, local wisdom tends to run into marginalization so that it is completely lost (Choesin, 2002 cited in Rasna\&Tantra, 2017). The local wisdom should be able to become a milestone in the community in order to preserve the cultural heritage and the natural resources. Meanwhile, a transformation towards sustainability is urgently needed for our planet, and every other living thing on it including the resources it provides. Therefore, this study aims at exploring the local wisdoms that still exist and develops at several springs in Singosari Malang. Locations were chosen based on the profile of the springs which still have good management based on the local wisdom that are passed on through generations. The springs include Sumber Biruand Sumber Nagan in Gunungrejo village, Singosari District Malang. The research approach used is ethnographic research. Interviews, focused discussions, and documentation were the techniques used to collect the data. The result is descriptively presented in a form of a history of the springs which is retold in the form of short story.
\end{abstract}

DOI: https://doi.org/10.26905/lw.v12i1.3704

@ 2017 The Authors. Published by GKAK UNMER Malang

*Corresponding Author: diannovita@ub.ac.id

\section{Introduction}

Efforts in nature conservation can be carried out through culture. Local culture is able to lift and influence the way of thinking of ordinary people to preserve nature such as springs. In order to preserve the wáter resources, many strategies have been done by the locals. One of them is through the oral tradition or stories behind the conservation of water resources. In this case, people holds important role in preserving the water resources. On the contrary, the fact revelas that people are getting less aware of this role. This can be seen from the number of wáter resources or spring in Malang city that was initially sanctified but then commercialized.

Local traditions in Indonesia itself, especially on the island of Java from the beginning can be said to be a religious tradition but in a simple form. Communities in 
Indonesia strongly carry out religious and magical institutions because they think they will get curses and disasters from their ancestors if they break them.

Local wisdom practically undergoes reduction in recent times, especially for the younger generation (millennial) who have been exposed by the advance of technology and streams of information and entertainment from many cultures. The essence of local wisdom has been changed into formality, instead of inhabiting our way of thinking and way of living. Hence, various researches on local wisdoms learning need to be done to enhance the appreciation and to preserve our culture and resources, including the collection of oral tradition such as folktale.

As one of oral tradition for, Javanese proverb says that nature is actually the genuine teacher, "Alam Iki Sejatining Guru". The proverb means that Javanese people consider the universe as God's greatness, that they believe nature as guardian and sources of life values. Likewise, the proverb shows that nature shall not be exploited or neglected, for it shall be treated as students to their teachers; respectfully and wisely (Suprapto, 2015, pg. 48). This local wisdom as well as locals perspectives toward the natural sources hold prominent role to preserve their cultural heritage and identity (Liliweri, 2014, pg. 222)

Singosari society in Malang regency, East Java still maintains their tradition to respect ancestors and maintain natural balance. Apart from any rituals and tricks attached to the Nagan and Blue water resources, the ability of Singosari residents to be able to package and maintain culture, rituals of trust, and tolerance is proven to be able to maintain the sustainability of springs. Based on the data obtained, Singosari people still maintain oral traditions or local wisdom by believing in mystical stories related to story behind Sumber Nagan and Sumber Biru. Drs.Niels Mulder (quoted in Simanjuntak, 2016) states that the culture of Singosari society is depicted in the contents of spiritual and practice. This encourages people to maintain natural resources in the form of these springs with oral traditions, namely stories that are made and believed to exist.

By treasuring and through documentation of the local wisdoms in water resources area that managed to preserved the oral tradition, the researchers aim to turn the ecosystem narratives into stories. Furthermore, this research includes the history or the legend of water resources regarding the similarity of trees variety and vegetation near the area. Several locations have been chosen for they have been well preserved by the locals through generations. The water resources include Sumber Biru Springs and Sumber Nagan Springs. The two springs are amongst others that are considered to have good water quality and their local wisdoms similarly root from the history of Singosari and Majapahit kingdom (Pitaloka, 2016).

Sims and Stephens (quoted in Herminingrum and Junining, 2017) assert that folklore is a legend, myth, art, and tradition, constructing local wisdom which later became the moral-ethical teachings of the life of the local community. Folklore in Indonesia includes (a) folk language, (b) traditional expressions, (c) traditional statements, (d) folk poems and poems, (e) folk prose stories, and (f) folk songs (Danandjaja, 1986, p.22). To distinguish this story included in the myth or included in the legend, by paying attention to the collective (folk) which has a version of the story, because it can be determined the category of a story by knowing its collective (Danandjaja, 1986, p.51).

Local wisdom practices aimed at conserving environment have been done by many locals. Like Osing people mostly believe in a spirit called Danyang who guards the 
water sources (Sumarmi, 2015). The locals believe that the spirit demands the people surrounding to give him regular offerings such as jenangabang and sego bolong especially when they have special ceremonies at least once in a year. Another example of local wisdom as a way to preserve the environment is showed by Rim-Rukeh et al (2013 cited in Hasbiah, 2015). The locals maintain the forest by using taboos about holy places to conserve the forest and other natural resources.

Local wisdom is one the solutions to environmental issues by raising the local values to balance and conserve the environment (Fahrianoor et al 2013 cited in Hasbiah, 2015). As local wisdom practices close to human daily life, it will be reflected by the people to maintain the nature. Like Singosari people created a story of Sumber Nagan and Sumber Biru as holy places, these change people's attitudes to maintain and preserve springs as a source of human needs. One proof of community behaviour is improving facilities at the source location, and performing rituals at certain moments.

\section{Methodology}

Ethnography was used to conduct this study. Qualitative data related to local wisdom were obtained through several techniques. Interview and observation were used to gain the main data, while secondary data were taken from related document analysis. The study took place in two venues Sumber Biru Springs located in Gunungrejo Village and Sumber Nagan Springs situated in Candirenggo Village. The main data were obtained by asking to the informant who is a guide of the springs and a local citizen as well. This open-ended interview was supported by audio recording feature to hold the valid data. The data also were dug up around 3 month's observation with digital camera to enrich the data. In addition, by using video recording feature, finding out the similarity of trees variety and vegetation can be obtained as well. The results of data were analyzed through several steps. Firstly, the qualitative data were reduced based on the needs. Data classification is the next step to categorize into two parts based on the similarity of source and content. The last is data display to show the feasibility of results which considered the focus of the study.

\section{Findings and Discussion}

\subsection{Findings}

Based on interview, Sumber Biru and Sumber Nagan include to natural form and no one knows how the springs are formed. Sumber Biru is situated in Gunungrejo Village Singosari District. According to locals, it is called Sumber Biru since it is located in Dusun Biru. Whereas, informant stated Biru is taken from the clear water comes up from spring as if it has blue color. The spring itself comes out from the roots of a big Banyan Tree (the family of Moraceae). It is commonly known as weeping fig, benjamin fig or ficus tree and can be found a lot in Asia especially Thailand and Indonesia. The spring is used by the locals to fulfill the needs of clear water daily such as drink, taking a bath, irrigation, even for recreation. Through pipes, the clear water is flowed to houses.

Informant said that Sumber Biru is also known as the source of life. This name comes from a story during the colonial period. There was an Indonesian soldier who collapsed because he was hit by Dutch bullets near the Sumber Biru location which was later found by locals and given a drink from Sumber Biru water and miraculously the 
wound recovered quickly and the army gained the power of being immune to all types of weapons so he was able to defeat the Dutch troops alone. From that incident, the locals around called it the Source of Life (Sumber Panguripan). On certain days, many locals from various regions even from outside of Malang visit this location because of the safety and efficacy of this spring, especially on the night of Suro (Muharram), which is the New Year in the month of Hijri such as Jakarta, Banyuwangi, Surabaya, Blitar, and others.

Sumber Nagan, located not too far from Sumber Biru, is located in Pesanggrahan Hamlet, Candirenggo Village, Singosari District. It was said by locals that this source is connected with Sumber Biru even though the location different. Nagan comes from the word Naga as it is believed by the surrounding community that the place is guarded by a dragon. According to the informant, Nagan is a place for storing rice, like a rice barn. In ancient times this location became the destination of many people who came from places many miles away to take their food stalls and take water and baths at this venue so that a settlement was built around this Sumber Nagan.

The existence of two versions of the story about Sumber Nagan indicates that this story is included in the story of folk prose where the condition of the prose story is the existence of versions according to the owner of the story. In other words this story includes folk prose stories of a kind of individual legend. Individual legend is a story about certain figures, which are considered by those whose stories really happened (Danandjaja, 1986, p.73).

Nagan forms three layers of water channelled by pipes planted on a rock whose water is always flowing even in the dried season so that the local people depend on this site as a source of water supply. At the location of this source is found large and small rocks and bamboo plants. To arrive at the location, visitors must climb steep steps. Like Sumber Biru, the springs at Sumber Nagan also have efficacy. On one side at this source location there is also one place that is used for rituals seeking of healing. Even at that location a prayer for bathing and a prayer for drinking were added. Therefore, the location of this source is also visited by many visitors in addition to meeting their daily water needs, they also come to meditate and seek healing.

According to data obtained from informants through interviews and from residents visiting the location, this source has a story relationship with Mpu Gandring who purified his keris in Sumber Nagan so that it was sacred by the surrounding community. In addition, Mbah Slamet said that there was a spiritual being that guarded this source, namely Mbah Wiroguno and Sri Ayu Dewi Melati Putih. Regardless of whatever rituals and tuahs are attached to Sumber Nagan. The ability of local residents is able to package and maintain culture, rituals of trust, and tolerance is proven to be able to maintain the sustainability of this spring by maintaining and preserving oral traditions that are still alive in the community.

\subsubsection{Sumber Biru : The Healing Spring}

There was once a soldier who was badly hurt by the colonizer during the battle. A bullet went through his right chest. In pain, he went to the forest to find a help, but he found no one. He went further and he found a pond. He was about to wash his wound when he suddenly collapsed in the bank. During his collapse, the soldier dreamt an old man came to him and asked him to drink the water. Then he asked him, "Who are you?", the old man answered, "My name is Tugi Wulung, I am the keeper of this pond". Minutes 
later, he woke up, still in aching; the soldier remembered his dream and drank the water as requested by Tugi Wulung.

Unexpectedly, he felt the overflow energy through his body, the wound miraculously disappeared. He felt healthier, stronger and more alive.

He then went to the battle field. A Barrage of bullets hit his body but the entire bullet bounced, with only sharpened bamboo as a weapon he defeated the enemies.

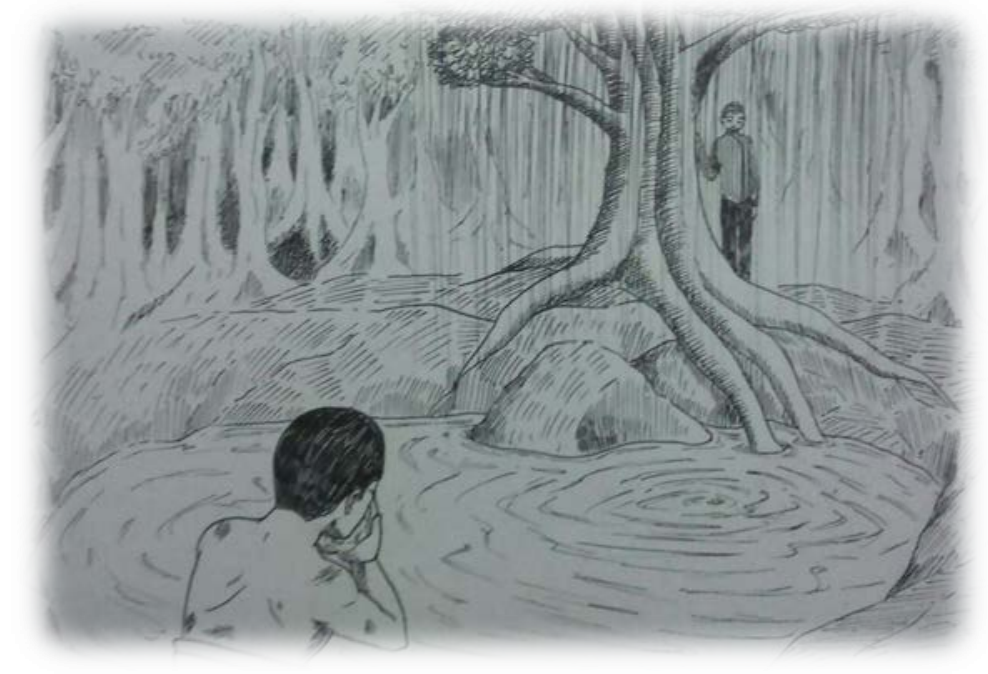

Figure 1.Tugi Wulung under ficus tree

Soon after he won the battle, he realized that he became immune to bullet. "It must be the water!", he said. Then he went back to the pond and he drank the water again. When he was about to leave, he tried to call Tugi Wulung to say thank you, he said "Tugi Wulung, thank you for your help, what can I do to pay you back?". Suddenly, there was a deep voice echoing around the pond, "All you need to do is taking care the pond, keep it clean in serene. Protect all of creatures living here, the animals, the plant and the Bayan tree. Do not let anyone cut down the Bayan tree, because he is the keeper of the spring!". The Soldier replied firmly, "I will!".

Since then, the soldier became the caretaker of the pond as his gratitude to the gift given to him, a second life.

Until now, the pond is still preserved. People called it as Sumber Biru, the healing fountain. It is so tranquil and scenic; the spring came out of the root of the Bayan tree upon it and it never run out. The bluish water has benefits the surroundings with prosperous life, not only the villagers but also the plants and animals.

\subsubsection{Sumber Nagan: The Fountain of Life}

It was warm summer weather in the village, Dewi Sri Ayu Melati Putih spent her days in the bank of the spring. She liked enjoyed the fresh air and tranquil ambience of the village where people around were so generous and friendly. Dewi Sri Ayu Melati Putih, as the caretaker of the spring was routinely visiting the spring to take care of it. She was beautiful guardian angel who was very friendly and kind-hearted. She liked to get along with the villagers who come to the Nagan, which was located near the spring. Villagers 
also thanked to have her as the caretaker of the spring, because by her presence, the spring was beautifully preserved.

The spring is the fountain of life for the villagers. It provides the fresh water for drink, rice field irrigation and their daily basis needs such as bathing, washing or just chilling out. Thus, the villagers were hand in hand with Dewi Sri Ayu Melati Putih to take care the spring.

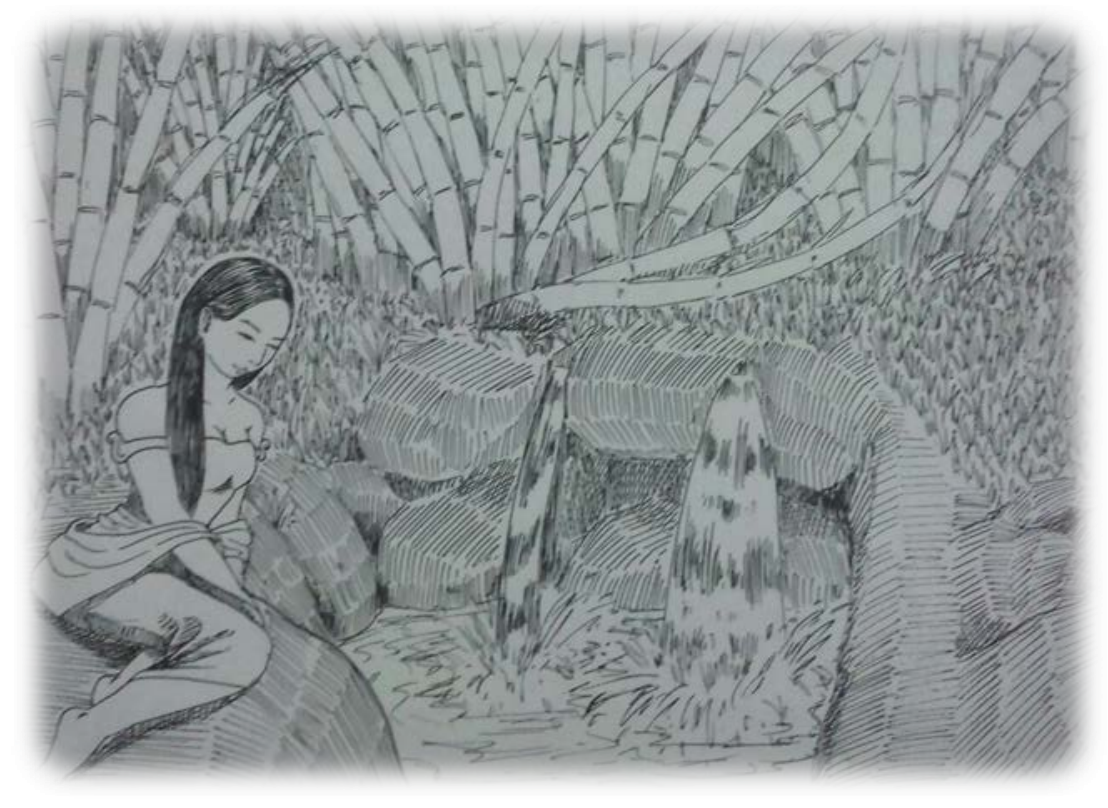

Figure 2.Dewi Sri Ayu Melati Putih

One day, there was a newcomer to the village. He was warm welcomed by the villagers and he was shown the Nagan, place where villagers stocked their rice. The villagers have advised him to taking care the surroundings and kept the Nagan and the spring clean. The newcomer ignored the advice, every time he washed the rice in the spring, he never cleaned it out. Consequently, the spring full of rice-wasted and blocked the water current from the spring to the village. It also made the spring flooding and watering the Nagan.

Meanwhile, in the spring, full of anger, Dewi Sri Ayu Melati Putih turned into a dragon and warned the newcomer who was washing his rice and wasted its waste in the spring.

She told him, "Because you were careless on the surroundings, the waste blocked the water current; consequently the villagers could not get the water and the spring flooding and watering the Nagan. Now your deed has caused the villagers run out of their water and food stock. You have to be responsible for this!"

The newcomer realised his mistake, stutteringly he replied the dragon "I am so sorry, I did not know that the trash will block the water current and cause this disaster. I promise I will take my responsibility on this!" 
The newcomer then cleaned up the spring. He took away the waste and reused it as husk. By the help of the villagers, within a week all the mess up was handled. The newcomer and the villager take care of the Nagan and preserved the spring as it was. Dewi Sri Ayu Melati Putih was happy seeing the spring clean and getting more beautiful with the jasmines planted by the villagers using the husk from rice-waste. Her role as the caretaker of the spring was crucial as well as the role of the villagers. The preservation of the spring was not only the responsibility of her but also all of the villagers, so they can benefit the spring gave prosperously. Since then, the spring is called as Sumber Nagan, the fountain of life.

\subsection{Discussion}

Efforts in nature conservation can be carried out through culture. Local culture is able to lift and influence the way of thinking of ordinary people to preserve nature such as springs. Based on the data obtained that Singosari people still maintain oral traditions or local wisdom by believing in mystical stories related to story behind Sumber Nagan and Sumber Biru. The story of the origin of Sumber Nagan and Sumber Biru is included in folklore because it is included in the type of folk prose story. The existence of two versions of the story about Sumber Nagan indicates that this story is included in the story of folk prose where the condition of the prose story is the existence of versions according to the owner of the story. In other words this story includes folk prose stories of a kind of individual legend. Individual legend is a story about certain figures, which are considered by those whose stories really happened (Danandjaja, 1986: 73).

\section{Conclusion}

The stories of the origin of Sumber Nagan and Sumber Biru are included in folklore because it is included in the type of folk prose story. Through the documentation of the oral traditions in several water conservations in Malang city, the ecosystem narratives are turned into interesting stories and might be used as attractive learning media and materials in English. Moreover, this is gradually conducted in order to awaken the cultural revival amongst our society in general, and the younger generation in more specific manner. Not only in Malang area, but also in other places, the results of the research shall inspire other places (water reservations) to maintain the oral tradition of their natural resources and springs for the balance of ecosystem in the future.

\section{References}

Danandjaja, James. (1986). Foklor Indonesia, Ilmu Gosip, Dongeng dan lain-lain.Jakarta: Grafiti Press.

Hasbiah, Astri. (2015). Analysis of Local Wisdom as an Environmental Conservation Strategy in Indonesia. Sampurasun e-Jurnal Vol. 01, No. )1 December 2015. Retrieved in http://journal.unpas.ac.id/index.php/sampurasun/article/view/19. Accessed on 14 January 2020 
Herminingrum, S., \& Junining, E. (2016). Socio-Cultural Life Of Kelud People In Connecting With Traditional Mitigation Effort Based On Local Wisdom. International Journal of Social and Local Economic Governance, 2(2), 127-135. doi:http://dx.doi.org/10.21776/ub.ijleg.2016.002.02.4

Liliweri, Prof. Dr. A. (2014). Pengantar Studi Kebudayaan. Bandung: Nusa Media.

Pitaloka, D.A. (2016). Telaga Purbadi Era Singosari dan Majapahit. Retrieved in https://www.terakota.id/telaga-purba-di-era-singosari-dan-majapahit/.

Rasna, I.W \&Tantra, D.K. (2017). Reconstruction of Local Wisdom for Character Education through the Indonesian Language Learning: An Ethno-pedagogical Method. Theory and Practice in Language Studies, Vol. 7, No. 12, pp. 1229-1235, December 2017. Retrieved http://www.academypublication.com/ojs/index.php/tpls/article/download/tpl $\underline{\mathrm{s} 071212291235 / 1336}$

Sumarmi. (2015). Local Wisdom of OsingPeople in Conserving Water Resources. Jurnal Komunitas 7 (1) (2015): 43-51. DOI: 10.15294/komunitas.v7i1.3429. Retrieved in http://journal.unnes.ac.id/nju/index.php/komunitas.

Suprapto, R. H. (2015). Kitab Petuah Warisan Leluhur Jawa. Yogyakarta: Laksana. 